\title{
MODERN TENDENCIES OF URBAN SETTLEMENT TRANSFORMATION IN ZAPORIZHIA REGION
}

\author{
Kseniia NELIPA \\ Taras Shevchenko National University of Kyiv, Ukraine \\ nelipka@mail.ua
}

\begin{abstract}
The system of urban settlement in industrial regions requires special attention in the post-industrial period. Intensive urbanization processes, unsatisfactory demographic situation, economic crisis and geopolitical instability in the region stipulate an uneven distribution of population, especially overpopulation of certain areas within Zaporizhia Region. The aim of this work is to study modern transformation of urban settlement in Zaporizhia Region. To reach the goal, we needed to consider the development of a modern urban settlement system in the region, to analyse population dynamics and to determine the share of urban population in the districts, to determine the influences of the regional capital on the regional urban settlement system, to analyse provision with social institutions in the cities of the region. To perform this study, we applied statistical, bibliographic, cartographic, analytic and synthetic methods, and analyzed the data presented by the Central Statistical Office in Zaporizhia region, as well as legal acts on issues of administrative and territorial division of Ukraine. The article presents the results of population dynamics analysis, compares the share of urban and rural population, and studies the share of urban population in the districts to total urban population in Zaporizhia region. We identified cities and urban villages that recently have moved from one population category of urban settlements to another, and analysed current changes in the provision with social institutions in the cities of the region. Thus, the article lays down the basic functioning and development problems of the urban settlement system in Zaporizhia region.
\end{abstract}

Key words: transformation, industrial region, city, urban village, inter-district centers.

DOI: http://dx.doi.org/10.17721/2413-7154/2016.75.35-39

UDC: [911.3:33]:314(477.64)

\section{СУЧАСНІ ТЕНДЕНЦІЇ ТРАНСФОРМАЦІЇ МІСЬКОГО РОЗСЕЛЕННЯ В ЗАПОРІЗЬКІЙ ОБЛАСТІ}

\author{
Ксенія НЕЛІПА \\ Київський начіональний університет імені Тараса Шевченка, Україна \\ nelipka@mail.ua
}

\begin{abstract}
Анотація: В постіндустріальний період особливої уваги потребує система міського розселення індустріальних регіонів. Інтенсивні урбанізаційні процеси, незадовільна демографічна ситуація, економічна криза та геополітична нестабільність в регіоні впливають на нерівномірний розподіл населення та перевантаженість окремих територій Запорізької області. Метою роботи $\epsilon$ дослідження трансформації міського розселення Запорізької області. В роботі необхідно розглянути процес становлення сучасної міської системи розселення в регіоні, проаналізувати динаміку чисельності та визначити частку міського населення в районах області, визначити вплив обласного центру на міську систему розселення Запорізької області, проаналізувати забезпеченість міст області закладами соціальної сфери. Були використані статистичні, бібліографічні, картографічні та аналітико-синтетичні методи дослідження. Під час написання роботи було проаналізовано дані Головного управління статистики в Запорізькій області та нормативно-правові акти з питань адміністративно-територіального устрою України. В роботі наведено результати аналізу динаміки чисельності, частки міського населення до сільського та частки міського населення в районах до загальної кількості міського населення в Запорізькій області. Визначені міста та селища міського типу, які перейшли з однієї категорії міських поселень за людністю до іншої. Проаналізовані зміни в забезпеченості міст області закладами соціальної сфери. Таким чином, в статті сформульовані основні проблеми функціонування та розвитку міської системи розселення Запорізької області.
\end{abstract}

Ключові слова: трансформація, індустріальний регіон, місто, селище міського типу, міжрайонні центри.

DOI: http://dx.doi.org/10.17721/2413-7154/2016.75.35-39

удк: [911.3:33]:314(477.64)

Постановка проблеми. Міські поселення $\epsilon$ головними складовими опорного каркасу розселення, від їх розвитку залежить соціально-економічний розвиток регіонів. Для другої половини ХХ століття було характерним активна індустріалізація та інтенсивне зростання міст, але на поч. XXI століття у зв'язку з економічною нестабільністю, занепадом промислового виробництва та продуктивних сил

(C) К. Неліпа спостерігаються негативні тенденції суспільних трансформацій, особливо в індустріальних регіонах.

Аналіз останніх досліджень і публікацій. Дослідженням міської системи розселення займалися Ю. І. Пітюренко, А. І. Доценко, М. Д. Пістун, В. О. Джаман, Л. Б. Заставецька, В. В. Загородній, Г. П. Підгрушний, К. В. Мезенцев, І. В. Гукалова, О. О. Афоніна, Г. М. Заваріка, Е. І. Благова та інші. Їх наукові праці присвячені структурі, формуванню 
та функціонуванню міської системи розселення, а також її взаємозв'язку з сільською.

Формулювання цілей та завдань статті. Метою роботи є дослідження трансформації міського розселення Запорізької області. Для досягнення поставленої мети вирішувалися такі наукові завдання:

- розглянути процес становлення сучасної міської системи розселення в Запорізькій області;

- проаналізувати динаміку чисельності та визначити частку міського населення в районах області за останні 25 років;

- визначити вплив обласного центру на міську систему розселення Запорізької області;

сформулювати основні проблеми функціонування та розвитку міської системи розселення регіону.

Виклад основного матеріалу. Формування систем міських поселень прямо залежить від рівня розвитку виробничих сил і особливостей їх розміщення на території країни, від характеру i величини територіально-виробничих комплексів [6]. Міське розселення включає поселення двох категорій - міста i селища міського типу. Особливістю виникнення і функціонування міських поселень $є$ їх зв'язок з несільськогосподарською, головним чином промисловою діяльністю [8].

У структурі регіональної системи розселення Запорізької області переважає міське населення. Характерною її ознакою є середній рівень щільності поселенської мережі, що зумовлено пізнім заселенням території (з ХІХ ст.), розвитком промислових центрів, нестачею питної води та порівняно посушливими кліматичними умовами в регіоні.

На даний момент міська система розселення Запорізької області налічує 14 міст (3 них 5 -обласного значення) та 22 селища міського типу. Перші міста в області почали поступово виникати на початку XIX ст., а вже з середини XX ст. кількість міських поселень стрімко почала зростати. 31950 р. по 1985 р. в Запорізькій області утворилося нових 6 міст (рис. 1) та 17 селищ міського типу (рис. 2) [4].

Узагальнюючим показником трансформації розселення є кількість населення. Порівнюючи дані чисельності міського населення 2015 року з даними 1990 року, наведеними Є.Благовою [1], можна дійти
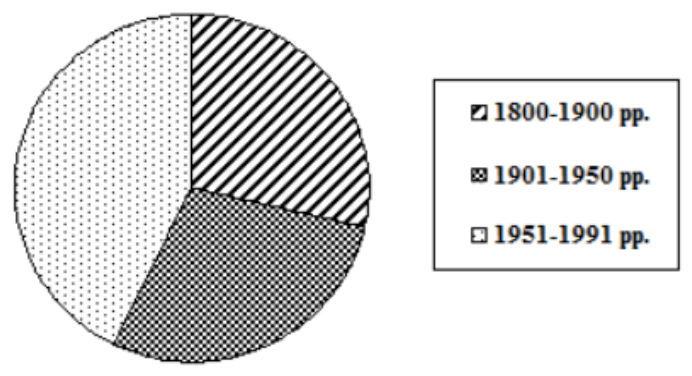

Рис. 1. Співвідношення кількості поселень Запорізької області, які отримали статус міста за період 18001991 рр. (складено за матеріалами [4]). висновку, що сучасна система міського розселення Запорізької області за останні 25 років значно трансформувалася. Збільшилася частка міського населення за рахунок відтоку сільських мешканців до міст та селищ міського типу. Найбільше ці процеси спостерігаються у Приазовському (33\% міських жителів проти 16\% у 1990 р.), Кам'янкоДніпровському (разом 3 Великобілозерським районом, оскільки останній був утворений у 1993 році з частини Кам'янко-Дніпровського району [7]: 71,2\% проти 52\%), Василівському (58\% проти 44\%) та Якимівському (45,3\% проти $32 \%$ ) районах (рис.3) [5]. Тільки в Бердянському районі спостерігаються тенденції до зменшення міського населення (82\% міських жителів проти 92\% у 1990 р.).

Найбільша кількість міських жителів припадає на ті райони, в яких знаходяться міста обласного значення (Запорізький, Бердянський, Мелітопольський, Токмацький, Кам'янко-Дніпровський), а найменше на прибережні райони (Приазовський, Приморський) та райони, які знаходяться на периферії (Розівський, Вільнянський). У Великобілозерському районі взагалі відсутнє міське населення (рис. 4).

При порівнянні міст за людністю виявлені дуже різкі переходи з однієї категорії міст за людністю в іншу. Підтвердженням чого є мала кількість середніх та малих міст (20-50 тис. осіб) в регіональній системі розселення Запорізької області. У 2015 році м. Дніпрорудне та м. Пологи перейшли з групи міст за людністю населення 20-50 тис. осіб до групи міст 3 кількістю населення менше 20 тис. осіб [5].

В Україні до міст відносять поселення, що мають понад 10 тис. жителів, а також менші за людністю поселення, що історично склалися як міста. В Запорізькій області у м. Молочанськ у 2015 році налічувалось 6781 особа. Тобто людність в поселенні набагато менша, ніж потрібно для отримання статусу міста.

Така сама ситуація існує і з селищами міського типу в області. Указом Президії Верховної Ради УРСР у 1981 році, до категорії селищ міського типу можуть бути віднесені населені пункти при промислових підприємствах, будовах, залізничних вузлах, гідротехнічних спорудах, підприємствах 3 виробництва та переробки сільськогосподарської продукції, а також населені пункти, на території

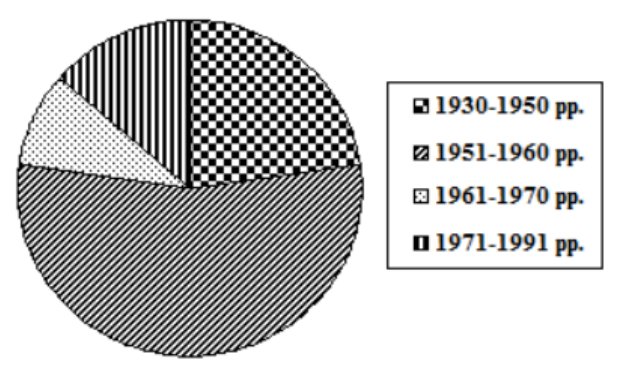

Рис. 2. Співвідношення кількості поселень Запорізької області, які отримали статус міста за період 1930-1991 рр. (складено за матеріалами [4]). 
яких містяться вищі та середні спеціальні навчальні заклади, науково-дослідні установи, санаторії та інші стаціонарні лікувальні та оздоровчі заклади, які мають державний житловий фонд, 3 кількістю населення понад 2 тисячі осіб, 3 яких не менш як дві третини становлять робітники, службовці та члени їх сімей. В Україні прийнято дві ознаки для виділення селищ міського типу: людність та питома вага робітників і службовців, зайнятих у несільськогосподарських галузях господарства [2].

В Запорізькій області за кількістю населення на даний момент не відповідають статусу селища міського типу такі поселення: смт. Залізничне
(Гуляйпільський район), смт. Кам’яне (Вільнянський район) та смт. Тернувате (Новомиколаївський район). Їх частка в загальній кількості селищ міського типу області складає 13,6\%. Трохи більше відмітки 2000 осіб знаходяться смт. Комиш-Зоря (Більмацький район) та смт. Нововасилівка (Приазовський район).

Таким чином, необхідно переглянути застарілу класифікацію міських поселень за людністю та розробити нову, яка більш повно могла б охарактеризувати сучасний стан міського розселення регіону та країни в цілому.

Селища міського типу виконують роль місцевих регіональних центрів, які забезпечують

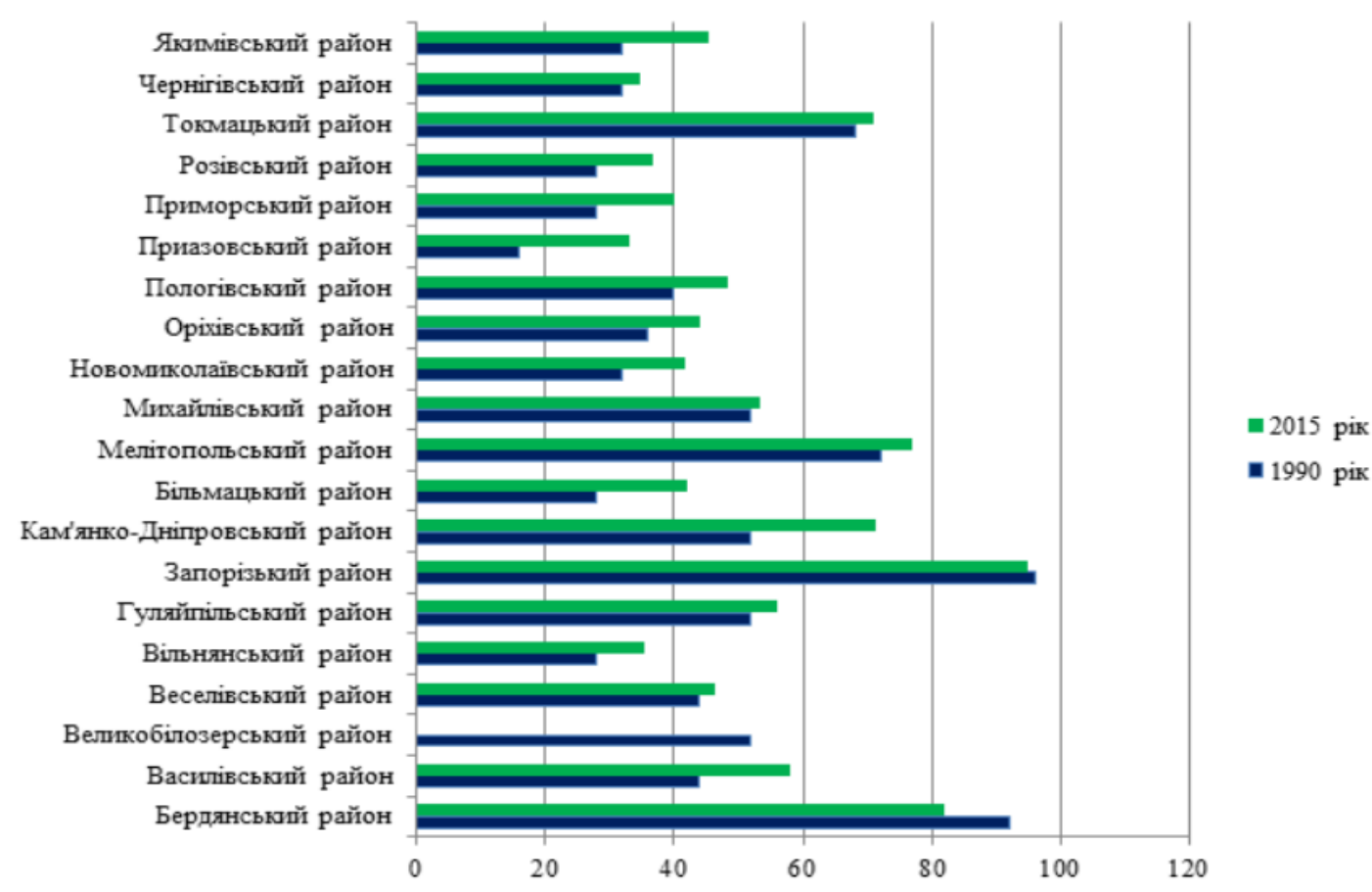

Рис. 3. Кількість міського населення по районах Запорізької області (\%) (складено за матеріалами $[1,5])$.

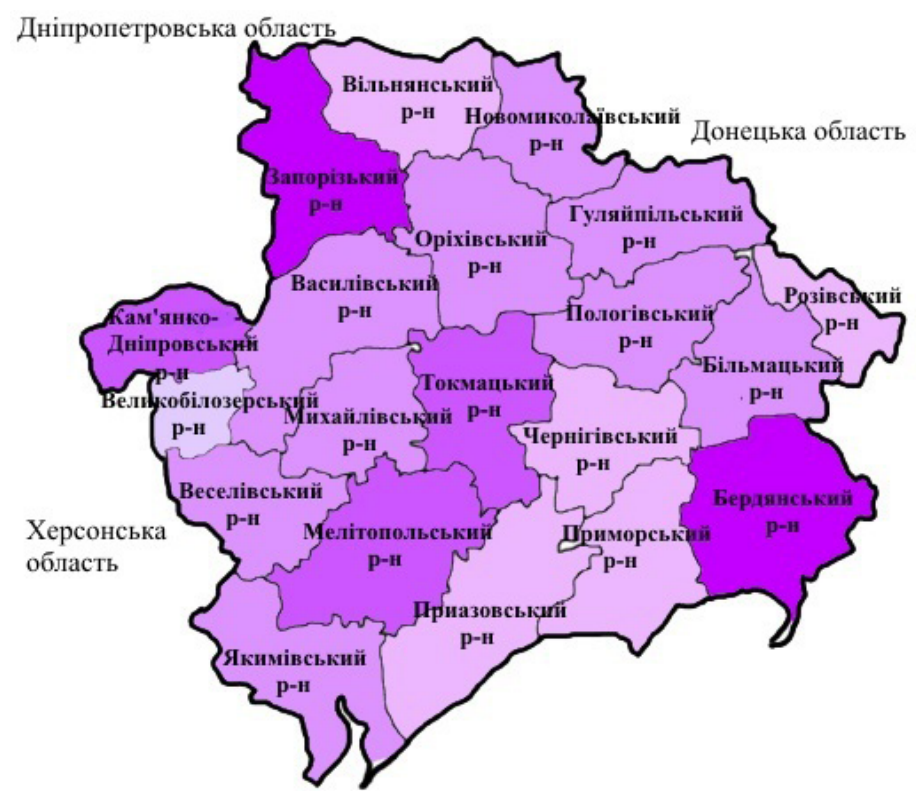

Умовні позначення:

Кількість міського населення у \%

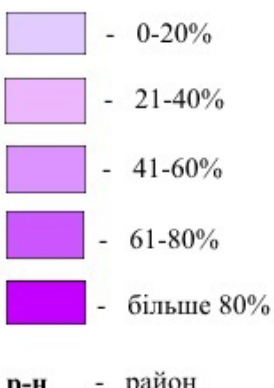

p-H - район

Рис. 4. Кількість міського населення в районах Запорізької області по відношенню до сільського населення у 2015 р. (складено за матеріалами [5]) 
Таблиия 1 .

Частка міського населення районів в загальній кількості міського населення Запорізької області станом на 01.12.2015 р. (Складено за матеріалами [5]).

\begin{tabular}{|c|c|c|c|}
\hline № & Назва району & $\begin{array}{c}\text { Кількість міського } \\
\text { населення в } \\
\text { районі, осіб }\end{array}$ & $\begin{array}{c}\text { Частка міського населення } \\
\text { районів в загальній } \\
\text { кількості міського } \\
\text { населення області, \% }\end{array}$ \\
\hline 1 & Запорізький & 779495 & 57,25 \\
\hline 2 & Мелітопольськнй & 159534 & 11,72 \\
\hline 3 & Бердянський & 117924 & 8,66 \\
\hline 4 & Кам'янко-Дніпровський & 67767 & 4,98 \\
\hline 5 & Токмацький & 39238 & 2,88 \\
\hline 6 & Василівський & 37506 & 2,75 \\
\hline 7 & Оріхівськнй & 20406 & 1,50 \\
\hline 8 & Пологівський & 19640 & 1,44 \\
\hline 9 & Вільнянськнй & 16930 & 1,24 \\
\hline 10 & Мнхайлівськнй & 15633 & 1,15 \\
\hline 11 & Якнмівськнй & 15410 & 1,13 \\
\hline 12 & Гуляйпільський & 15196 & 1,12 \\
\hline 13 & Приморський & 12124 & 0,89 \\
\hline 14 & Веселівськнй & 10038 & 0,74 \\
\hline 15 & Більмацькнй & 9482 & 0,70 \\
\hline 16 & Прназовськнй & 9155 & 0,67 \\
\hline 17 & Новомиколаївський & 6819 & 0,50 \\
\hline 18 & Чернігівськнй & 6045 & 0,44 \\
\hline 19 & Розівськнй & 3316 & 0,24 \\
\hline 20 & Великобілозерськнй & 0 & 0 \\
\hline
\end{tabular}

Таблиия 2.

Забезпеченість міст Запорізької області закладами соціальної сфери станом на 01.01.2016 p.

(складено за матеріалами [5]).

\begin{tabular}{|c|c|c|c|c|c|c|c|c|c|c|c|c|}
\hline Мiсто & $\stackrel{m}{M}$ & 跣 & $\stackrel{\partial}{E}$ & 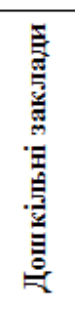 & 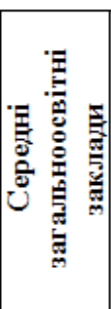 & 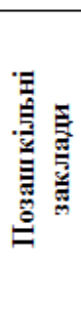 & 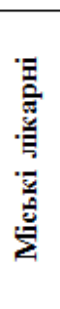 & 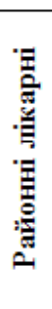 & 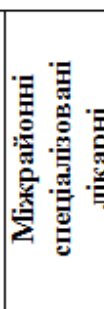 & 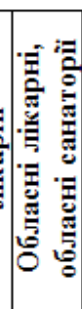 & 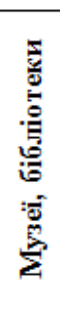 & 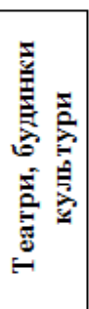 \\
\hline Запоріжжя & 17 & 14 & 16 & 143 & 122 & 64 & 36 & 1 & - & 25 & 26 & 18 \\
\hline Мелітополь & 7 & 4 & 6 & 26 & 26 & 11 & 4 & 1 & 8 & - & 9 & 5 \\
\hline Бердянськ & 3 & 3 & 4 & 15 & 21 & 8 & 3 & - & 4 & 1 & 9 & 6 \\
\hline Енергодар & 1 & - & - & 11 & 10 & 6 & 2 & - & - & - & 7 & 3 \\
\hline Токмак & - & 1 & 1 & 8 & 10 & 3 & - & 1 & 1 & - & 5 & 1 \\
\hline Василівка & - & 1 & - & 4 & 5 & 2 & - & 1 & 1 & - & 3 & 2 \\
\hline Вільнянськ & - & - & - & 3 & 4 & 4 & - & 1 & 1 & - & 2 & 1 \\
\hline Гуляйполе & - & - & 1 & 5 & 4 & 1 & - & 1 & 2 & - & 6 & 1 \\
\hline Дніпрорудне & - & 1 & - & 5 & 5 & 2 & 1 & - & - & - & 3 & 1 \\
\hline Кам'янка-Дніпровська & - & - & - & 3 & 4 & 3 & - & 1 & - & - & 2 & 1 \\
\hline Молочанськ & - & - & 1 & 2 & 3 & 2 & - & 1 & 1 & - & 2 & 1 \\
\hline Opixiв & - & 1 & - & 4 & 5 & 1 & - & 1 & - & - & 3 & 1 \\
\hline Пологи & - & - & 1 & 6 & 5 & 2 & - & 1 & - & - & 1 & 2 \\
\hline Приморськ & - & 1 & - & 3 & 5 & 3 & - & 1 & - & 1 & 2 & 1 \\
\hline
\end{tabular}


навколишні сільські поселення первинними формами обслуговування. Важливою особливістю селищ міського типу є сприяння функціонуванню і розвитку міст, насамперед їх виробничої діяльності - забезпечення робочою силою, місцевими сировинними ресурсами, створення умов проживання для працівників зайнятих у містах тощо [8].

Тому потрібно поліпшити систему обліку селищ міського типу та упорядкувати їх структуру. Необхідно відродити історичну форму міських поселень, таких як містечка.

Мiста 3 вигідним географічним положенням та ті, в яких була дуже розвинута промисловість, набули значення центрів субрегіональної системи розселення регіону. Вони відіграють важливу роль в організації економічного i соціального розвитку області. Але найбільший вплив на міське розселення регіону відіграє м. Запоріжжя та прилеглі до нього поселення. Таким чином, 57,2\% всього міського населення області зосереджено у м. Запоріжжя та Запорізькому районі (табл.1). В 5 разів менше міського населення в Мелітопольському районі (11,7\%), ніж в Запорізькому. В Кам'янко-Дніпровському районі (4,9\%) вдвічі менша кількість міського населення, ніж в Бердянському (8,6\%). Менше 1\% міських жителів в області припадає на 8 районів: Приморський $(0,89 \%)$, Веселівський $\quad(0,74 \%), \quad$ Більмацький $\quad(0,70 \%)$, Приазовський $(0,67 \%), \quad$ Новомиколаївський $(0,50 \%)$, Чернігівський $(0,44 \%)$, Розівський $(0,24 \%)$, Великобілозерський $(0 \%)$. Тобто майже в половині районів області відсутній стійкий опорний каркас міського розселення, в результаті чого райони відстають за своїм соціально-економічним розвитком.

Тому в регіоні доцільно розвивати центри міжрайонного значення, які диверсифікували б функції обласного центру, наблизили б деякі функції до споживачів. Міжрайонні системи розселення формуються на основі об'єднання декількох районних систем навколо центрів, в яких зосереджені об'єкти міжрайонного значення. Міжрайонні центри одночасно виступають центрами районних, кущових та елементарних систем розселення [3]. В Запорізькій області такими центрами $є$ найфункціональніше розвинені міста - Запоріжжя, Мелітополь, Бердянськ, Енергодар, Токмак та Пологи.

До складу Запорізької міжрайонної локальної системи розселення (МЛСР) відносяться населенні пункти Запорізького, Вільнянського, Василівського та Оріхівського районів. Мелітопольська МЛСР складається 3 Мелітопольського, Веселівського, Якимівського, Приазовського районів. До Бердянської МЛСР відноситься Бердянський та Приморський райони. До невеликих МЛСР, за незначним впливом на навколишні райони, можна віднести ЕнергодарКам'янко-Дніпровську МЛСР, Токмацьку МЛСР та Пологівську МЛСР.

Але не вся територія Запорізької області потрапляє під вплив цих центрів. Перекриття ㄲi площі зонами впливу міст $є$ важливим показником рівня соціально-економічної зрілості території.
Створення нових центрів (полюсів зростання) як джерел інновацій призведе до створення так званих коридорів розвитку, які даватимуть імпульс до соціально-економічного зростання всієї території регіону [3]. Доцільним буде створення таких центрів в смт. Більмак (Куйбишеве) та смт. Новомиколаївка, які знаходяться на периферії від головних міжрайонних локальних систем розселення області.

Великі міста виступають в ролі інвестиційних центрів, а малі міста $€$ переважно центрами для обслуговування сільських поселень. В містах Запорізької області, у зв'язку 3 переходом до ринкової економіки, економічною нестабільністю в країні, необхідні зміни у напрямку відмирання тих виробництв, які є неконкурентними у даному регіоні, диверсифікації структури господарства.

Розвинутість соціальної сфери відіграє роль активного притягувального чинника для населення, стимулу і зростання його кількості в містах. Основними складовими соціальної сфери $\epsilon$ діяльність i, відповідно, матеріально-технічні засоби та і організаційні форми іiі здійснення, що забезпечують - побутове культурне обслуговування населення, задоволення житлових потреб дошкільне виховання й освіту, охорону здоров'я, підготовку кваліфікованих кадрів спеціалістів і робочої сили і тощо. Зосередження цих видів діяльності властиве тільки міським поселенням, тобто $є$ однією із закономірностей їх формування та розвитку[8].

В Запорізькій області найбільша кількість закладів соціальної сфери припадає на Запоріжжя, Мелітополь та Бердянськ (табл. 2), оскільки в них зосереджено 75,9\% міського населення області. На даний момент вищі навчальні заклади (ВН3) та філії інших вищих навчальних закладів зосереджені в найбільших містах області - Запоріжжі, Мелітополі, Бердянську, Енергодарі. В більшості інших міст області функціонують тільки коледжі, технікуми та професійно-технічні училища (ПТУ). У Вільнянську та Кам'янці-Дніпровській взагалі відсутні заклади вищої та професійно-технічної освіти. Порівнюючи статистичні дані, наведені С. Благовою [1], за останні 30 років збільшилася кількість ВНЗ у Запоріжжі (3 4 до 17 ВН3), Мелітополі (з 2 до 7 ВН3) та Бердянську (3 1 до 3 ВНЗ). Кількість технікумів у цих містах не змінилася, а кількість ПТУ, окрім Мелітополя, зменшилася. В Енергодарі за досліджуваний період з'явився перший у місті ВНЗ. У малих містах області простежується негативна динаміка до зменшення та зникнення ПТУ. У Пологах зменшилася кількість ПТУ на 66,6\%, а в таких містах, як Василівка, Дніпрорудне, Оріхів, взагалі перестали функціонувати.

Найменше дошкільних та середніх загальноосвітніх закладів припадає на м. Молочанськ. В Мелітополі за 25 років кількість дошкільних закладів зменшилася на 53,6\% [5], і на даний момент в місті існує проблема нестачі місць для всіх бажаючих.

В 9 містах області відсутні міські лікарні i функціонують тільки районні. Найбільше 
міжрайонних спеціалізованих лікарень різного профілю знаходиться в Мелітополі та Бердянську, що позитивно впливає на їх домінування в МЛСР. В інших містах області знаходяться загалом тільки міжрайонні протитуберкульозні диспансери.

Для визначення рейтингу міст Запорізької області за забезпеченістю закладами соціальної сфери було запропоновано наступну бальну шкалу оцінювання:

1). ВНЗ - 1 бал (б), технікуми, коледжі - 0,5 б, ПТУ - 0,25 б;

2). Середні загальноосвітні заклади - 1 б, дошкільні заклади - 0,5 б, позашкільні заклади $-0,25$ б;

3). Обласні лікарні, обласні санаторії - 2 б, міжрайонні спеціалізовані лікарні - 1,5 б, районні лікарні - 1 б, міські лікарні - 0,5 б;

4). Музеї, бібліотеки, театри, будинки культури $-0,25$ б.

В результаті проведення бального оцінювання міст Запоріжжя отримало 317,5 балів, Мелітополь - 70,75 б, Бердянськ - 49,25 б, Енергодар - 21,5 б, Токмак - 19,5 б. Найменше балів (по 8) отримали міста Молочанськ та Кам'янка-Дніпровська. Це пояснюється тим, що вони знаходяться дуже близько до міст обласного підпорядкування Токмака та Енергодара, в яких зосереджена більшість головних закладів соціальної сфери даних районів.

Отже, міста Запорізької області забезпечені закладами соціальної сфери нерівномірно. Спостерігається тенденція до зменшення таких закладів у малих містах, що нерозривно пов'язано зі зменшенням кількості населення за останні 25 років, та відбувається їх концентрація у великих містах області. Тому необхідно розвивати заклади соціальної сфери у малих містах та селищах міського типу за для більш рівномірного забезпечення населення області соціальними благами, яке призведе до зменшення відтоку молоді у великі міста.

Висновки. Проаналізувавши зміни в міській системі розселення Запорізької області можна зробити такі висновки:

- сучасна система міського розселення області сформувалася ще за радянський період i характеризувалася інтенсивними урбанізаційними процесами у другій половині ХХ ст.;

- в результаті відтоку населення 3 сільських поселень у міста за останні 25 років майже в усіх районах області збільшилася частка міського населення;

- найбільша кількість міських жителів припадає на ті райони, в яких знаходяться міста обласного значення, а найменше - на прибережні райони та райони, які знаходяться на периферії;

- деякі міста та селища міського типу перейшли до іншої категорії міських поселень за людністю, в результаті чого необхідно перевести деякі міста в статус селищ міського типу, ввести до категорії міських поселень таку історичну форму як містечка та вдосконалити класифікацію міських поселень;

- більше половини міського населення області сконцентровано в Запорізькому районі, що призводить до нерівномірного розвитку території регіону та до поляризації поселень;

- простежуються зміни в забезпеченості міст Запорізької області закладами соціальної сфери: збільшується їх кількість у великих та середніх містах, та зменшується - в малих;

- необхідно розвивати центри міжрайонного значення, які диверсифікували б функції обласного центру.

\section{References:}

1. Blagova E.I. Formirovanie sistemy rasseleniâ subregional'nogo urovnâ $v$ usloviâh intensivnogo razvitiâ obŝestvennogo proizvodstva (na primere Zaporožskoj oblasti) [Formation of sub-regional level of settlement system in terms of public production intense development (on the example of Zaporizhia region). PhD Thesis. Kyiv, 1990, 224 p. (In Russian).

2. Docenko A.Ì. Teritorìal'na organizaciâ rozselennâ (teoriâ ta praktika): monografiâ. [Territorial organization of settlement (Theory and Practice): Monograph]. Kyiv, 2010, 529 p. (In Ukrainian).

3. Zastavec'ka L. B. Sistemi rozselennâ i geoprostorovì problemi vdoskonalennâ administrativno-teritorial'nogo ustrôu Ukraïni. [Settlement systems and geospatial problems of improving the administrative-territorial division in Ukraine]. Ternopil, 2013, 332 p. (In Ukrainian).

4. Official web-portal of the Verkhovna Rada of Ukraine. Access mode: http://rada.gov.ua/ (In Ukrainian).

5. Official website of the Central Statistical Office in Zaporizhia region. Access mode: http://www.zp.ukrstat.gov. ua (In Ukrainian).

6. Pìtûrenko Û.Ì. Rozvitok mist ì mì'ke rozselennâ v Ukraïns'kìj RSR. (Osoblivostì rozvitku ì rozmîsennâ, tipologiâ, teritorial'ni sistemi i perspektivi). [Urban development and urban settlement in the Ukrainian SSR. (Features of development and location, typology, territorial systems and perspectives)]. Kyiv, 1972, 187 p. (In Ukrainian).

7. Resolution of the Verkhovna Rada of Ukraine "On establishment of Velyka Bilozerka district in Zaporizhia region"] dated 03 February 1993 N. 2980-XII (In Ukrainian).

8. Rozselennâ v Ukraïni: problemi i perspektivi. [Resettlement in Ukraine: problems and perspectives]. Ed.: Danilišin B. M. Kyiv, 2006, 269 p. (In Ukrainian). 